\title{
NÆRPOLITI OG KRIMINALITETSBEKJEMPELSE
}

\section{AV POLITIMESTER BJøRN HAREIDE}

Generally speaking, the police are a part of society's collective effort to promote and confirm the legal protection of its citizens, their security and their common welfare. This is stated in the objectives clause of the Police Act. In our police district, however, we have a vision of being a cultural institution which takes care of, employs and conveys basic values of importance to society, such as solidarity and helpfulness, justice and equality, setting limits, renewal and rebuilding. This is a vision for a police that wishes to serve the individual as well as the community. It is our belief that community policing represents the best way to accomplish these goals. Community policing has something to do with how the organization is structured, but most of all, it has got to do with attitudes. Community policing is a way of doing police work, but it is also a way of relating to the public.

Fighting crime comprehends preventing crime, uncovering crime and pursuing crime up to a valid conclusion. Through the promotion and confirmation of citizens' legal protection, it provides security, which is a basic condition for human life and welfare. But the insurance of public security is not only a matter of obtaining crime prevention results, but also of how we obtain them. The citizenry do not benefit from the prevention of crime if these goals are reached through methods that contradict the ethical foundation and moral demands of our society.

The question of whether the police will succeed in their future effort to fight crime is largely dependent on how we manage to relate to juveniles. When we face this group, community policing should be particularly helpful in establishing the trust and respect necessary for doing a satisfactory job. In 1999, the Government introduced its plan on fighting juvenile delinquency, which included a contribution from the Ministry of Justice and the police called, "On an even keel." This document provides an important step towards implementing community policing, yet it is our belief that goals of justice would be furthered by granting the police an even greater role in specific prevention than the current plan suggests. *

\section{Innledning}

Min bakgrunn for å innlede til debatt om emnet "Nærpoliti og kriminalitetsbekjempelse" er tjeneste som politimester i 7 år etter først å ha vært førstestatsadvokat og statsadvokat i 13 år og forut for dette politijurist og dommerfullmektig. Jeg gjør tjeneste $\mathrm{i}$ et middels stort politidistrikt med 10 driftsenheter (politista-

\footnotetext{
* Title in English: Community Policing and Crime-Fighting. Orginal in Norwegian.
} 
sjon og lensmannskontor) og sentrale stabsfunksjoner. Mitt innlegg vil bære preg av mine erfaringer som politileder.

Det jeg her fremfører skal ikke være et foredrag eller en forelesning, men et hovedinnlegg til debatt.

Etter denne innledningen vil jeg si noe om kriminalitetsbekjempelsens innhold og resultat. Dernest følger noen bemerkninger om nærhet mellom politi og befolkning, før jeg berører hvilke forventninger politiet må forholde seg til. Jeg gir deretter en oversikt over og noen betraktninger omkring Regjeringens handlingsplan mot barne- og ungdomskriminalitet, før jeg avslutter med en kort beskrivelse av hvorledes vi i vårt politidistrikt har forsøkt å avveie spørsmålet om nærhet til befolkningen med de andre hensyn som må vektlegges i arbeidet med kriminalitetsbekjempelse. Helt til slutt vil jeg omtale vårt politidistrikts visjon om å være en kulturinstitusjon, som tar vare på, anvender og formidler grunnleggende verdier av betydning for rettssamfunnet.

\section{Kriminalitetsbekjempelsens innhold og resultat}

Politiet skal gjennom forebyggende, håndhevende og hjelpende virksomhet være et ledd i samfunnets samlede innsats for å fremme og befeste borgernes rettssikkerhet, trygghet og alminnelige velferd for øvrig. Dette fremgår av politilovens formålsparagraf. For påtalemyndigheten er det ikke gitt tilsvarende formålsbeskrivelse i loven, men jeg har for egen del formulert følgende: Påtalemyndigheten skal ivareta samfunnets rett og plikt til å avdekke og forfølge straffbare handlinger, slik at borgernes grunnleggende behov for rettferdighet og sikkerhet oppfylles og slik at kriminalitet blir forebygget.

Når vi skal diskutere "nærpoliti" må vi avklare hva vi legger i dette begrepet. Det har intet entydig innhold, men gir mange assosiasjoner. Det nærmeste jeg kommer en forklaring av begrepet, er at det har noe å gjøre med organisasjonsstruktur, men mest med holdninger. Det er en måte å drive en del av politiarbeidet på - det er en måte å forholde seg til befolkningen på.

Å bekjempe kriminalitet betyr å hindre kriminalitet, avdekke kriminalitet og forfølge kriminalitet til en rettskraftig avslutning. Vi hindrer kriminalitet gjennom holdningspåvirkning og strategisk, problemorientert arbeid rettet mot enkeltpersoner, grupper og miljø. Vi avdekker kriminalitet gjennom etterretning og etterforskning og forfølger kriminalitet gjennom avsluttende påtalemessig vedtak og eventuell iretteføring av saken for domstolen. Denne kriminalitetsbekjempelsen vil fremme og befeste borgernes rettssikkerhet og gi trygghet. Trygghet er grunnleggende for menneskelig livsutfoldelse og velferd. Hva hjelper det om helsevesenet plastrer sine pasienter, dersom disse skrives ut til utrygghet. Trygghet gis ikke bare om vi forhindrer kriminalitet, men også når den kriminalitet som oppstår blir håndtert på en fornuftig måte. Det dreier seg imidlertid ikke bare om å oppnå resultater, men også om måten vi når dem på. Hva gagner det samfunnet om politiet når sine mål, dersom måten vi når dem på ikke samsvarer med rettssamfunnets etiske grunnlag og moralske krav? 


\section{Nærhet mellom politi og befolkning}

Denne debatten skal dreie seg om nærpoliti og kriminalitetsbekjempelse. I en slik sammenheng er det nærliggende å spørre om nærhet alltid gir et fortrinn i kriminalitetsbekjempelsen.

Når kriminaliteten skal hindres vil nærhet gi politiet kunnskap om behovet for holdningspåvirkning og strategisk planlegging av tiltak. Nærhet gir også politiet kunnskap om miljø og kultur i omgivelsene og det gir befolkningen kjennskap til politiet. Befolkningens kjennskap til oss vil forhåpentligvis gjøre at politiet blir vist tillit. Det å ha tillit i en befolkning er en forutsetning for å kunne gjøre jobben tilfredstillende. Nærhet gir også politiet en følt forpliktelse til engasjement. Nærhet utvikler empati.

Politiets nærhet til befolkningen vil gi menneskene en følt risiko for oppdagelse av straffbare handlinger, men nærhet kan føre til at politiet utvikler "nærsynthet". Dette medfører at politiet ikke tar signaler på alvor fordi vi tror vi kjenner vedkommende og miljøet. Nærhet gir også personlige relasjoner, som kan føre til uheldige bindinger. Vi ser gjennom fingrene med forhold som burde påtales.

Nærhet er ressurskrevende. Det blir mindre tilbake til andre måter å drive politiarbeid på. I vår allsidige og krevende hverdag vil dette oppleves vanskelig.

For å avdekke kriminalitet vil nærhet kunne gi tilsvarende fortrinn og ulemper. På den positive siden vil jeg spesielt fremheve personlig kjennskap til enkeltpersoner, grupper og miljøer som en forutsetning for informasjonsinnhenting (etterretning). På den negative siden vil faren for mangel på faglig kunnskap og erfaring måtte fremheves. Slik mangel oppstår når spesialisering ikke etableres. Kriminaliteten har i dag så mange uttrykksformer at langt fra alt kan avdekkes med nærpolitiarbeid.

Når kriminaliteten skal forfølges frem til påtalevedtak og eventuell iretteføring, vil nærhet gi evne til å forstå individuelle forhold, men nærhet kan her svekke evnen til prinsipiell tenkning.

\section{Noen forventninger til politiet}

Nær sagt alle har forventninger til politiet. For politiet selv er det viktig å ha klart for seg de overordnede forventninger som er nedtegnet i styringsdokumenter og uttrykt i muntlige overleveringer. Den alminnelige politiske debatt er viktig å lytte til, men vi må hele tiden avveie denne opp mot de formelt uttrykte forventninger. De overordnede forventninger dreier seg i hovedsak om synlighet, ofte forstått som uniformert, patruljerende politi i gatene i en desentralisert organisasjonsstruktur ut over landet hvor få ansatte gjør tjeneste ved hver driftsenhet (politistasjon eller lensmannskontor). Like uttalt er forventningen om tilgjengelighet og hurtighet og kvalitet i oppgaveløsningen. Vi skal vise vennlighet og serviceinnstilling og være kostnadsbevisst.

Politiet selv vil i tillegg ha en arbeidssituasjon med vekt på helse, miljø og 
sikkerhet (HMS). Vi vil ha forutsigbarhet i balansen mellom arbeid og fritid og et faglig utviklende miljø med utfordrende oppgaver i hverdagen og med tilgang til planlagt kompetanseutvikling.

Det er ingen enkelt sak å avveie de ulike forventninger opp mot hverandre. Forventningen om synlighet og tilgjengelighet vil mange mene ikke står i motsetning til hverandre. Den praktiske hverdagen viser imidlertid noe annet. Skal vi være synlig i omfattende grad, vil tilgjengeligheten bli redusert på mange andre områder. Ofte må synligheten vike til fordel for tilgjengeligheten som følge av ressursmessige begrensninger. I mitt politidistrikt vil vi prioritere tilgjengelighet overfor et voldtektsoffer fremfor synlighet i gaten. Så konkret må avveiningene gjøres daglig. Synlighet vil også kunne stå i motstrid til kvalitet fordi stor grad av synlighet går på bekostning av kompetanseutvikling på ulike områder. Kvalitet og kosteffektivitet vil ofte stå i motstrid til hverandre. Likeledes kvalitet og hurtighet.

Det kan lett oppstå motstrid mellom de overordnede forventningene og etatens egne. Spesielt gjelder dette i forholdet mellom det overordnede ønsket om mange små desentraliserte driftsenheter og etatens egne ønsker om forutsigbarhet $\mathrm{i}$ balansen mellom arbeid og fritid. Tilsvarende vanskelig er det å kombinere ønsket om faglig utviklende miljø, HMS og kosteffektivitet med de mange små driftsenheter.

Ingen skal kunne si at det ikke er utfordrende å gjøre tjeneste i politiet.

\section{Regjeringens handlingsplan mot barne- og ungdomskriminalitet}

Spørsmålet om politiet vil lykkes i sitt fremtidige arbeid med kriminalitetsbekjempelse er i stor grad avhengig av hvorledes vi klarer å forholde oss til barn og unge. Stortinget ba i mai 1999 Regjeringen legge frem en samlet plan for innsats og tiltak som bekjemper kriminelle handlinger blant barn og unge. Allerede samme høst la Regjeringen frem Stortingsmelding nr 17 (1999-2000) "Handlingsplan for bekjempelse av kriminalitet blant barn og unge". Planen er utarbeidet i samarbeid mellom Barne- og familiedepartementet, Justisdepartementet, Kirke- utdannings- og forskningsdepartementet, Kommunal- og regionaldepartementet og Sosial- og helsedepartementet. Planen skal gjelde frem til 2004.

Justisdepartementets del av planen "På rett kjøl" deler det forebyggende arbeid blant barn og unge $i$ tre deler. Generell forebygging dreier seg om allmenn oppdragelse og tilrettelegging av miljø og samfunn slik at kriminalitet oppleves som en ikke ønsket del av dagliglivet. Spesifikk forebygging dreier seg om den målrettede innsats rettet mot særskilt risikoutsatte for å hindre utvikling av kriminell karriere. Individuell forebygging legger opp til tette og individuelt tilpassede opplegg for dem som allerede har begått straffbare handlinger.

Det generelle forebyggende arbeidet tar utgangspunkt i et tverretatlig samarbeid, hvor målet er å koordinere, målrette og øke effektivitet og kvalitet i den 
forebyggende innsatsen mot kriminalitet i lokalmiljøet gjennom en forpliktende og formalisert samordning mellom de ulike kommunale etater, politi og frivillige aktører. For min del vil jeg fremheve betydningen av å komme i bedre dialog med ulike typer frivillige interessegrupper som gjør en viktig innsats blant barn og unge.

Det spesifikt forebyggende arbeidet er problemorientert. Det er viktig med nærhet til befolkningen. Gjennom oppsøkende virksomhet, etterretning, samtaler og ulike former for aktiviteter vil politiet søke å hindre at barn og unge i risikosonen begynner med kriminalitet. I Oslo er det tatt initiativ til et prosjekt mot gjengkriminalitet. Programmets formål er å redusere gjengkriminaliteten, herunder voldsbruk, hærverk og barneran, og styrke arbeidet overfor unge som har vært barnesoldater i annet land. Dette skjer gjennom et bredt tverretatlig samarbeid og målrettede tiltak. Tilsvarende prosjekt skal etableres i Drammen og Kristiansand. Regjeringens plan forplikter videre politiet til å etablere faste politikontakter i samtlige grunnskoler og videregående skoler. Dersom det oppstår spesielle vanskeligheter skal skolen kunne henvende seg til den faste politikontakten. Denne ordningen er etter min oppfatning for ambisiøs. I vårt politidistrikt blir de forebyggende oppdragene fordelt mellom dem som på det aktuelle tidspunkt er på jobb og som behersker det aktuelle temaet. Regjeringens plan inneholder også et program for å motvirke ekstreme ungdomsmiljøer - og få ungdommene til å forlate disse miljøene.

Det individuelt forebyggende arbeidet dreier seg først og fremst om å oppklare straffbare handlinger blant barn og unge i den forebyggende hensikt å sette grenser og å la vedkommende stå til ansvar for sine handlinger. Det er viktig å effektivisere den såkalte straffesakskjeden slik at den unge lovbryteren kan møte en reaksjon i tett tilknytning til handlingen. Det er meget å hente på dette området i Norge. Det fortrinn jeg ser i den norske straffesakskjeden ved at politiet også har påtalemyndighet opp til et visst nivå er ikke på langt nær utnyttet. Det er egentlig ganske rart at vårt system ikke har gitt større gevinster på saksbehandlingstid. I Regjeringens plan ligger et pålegg om forsterket innsats i bruken av konfliktråd. Dette er noe vi må arbeide mer aktivt med i vårt politidistrikt. Vi tror på den forebyggende effekt av at lovbryteren konfronteres med konsekvensene av sine handlinger i møte med offeret. En slik konfrontasjon må imidlertid skje atskillig raskere enn $\mathrm{i}$ dag.

Konfliktrådsordningen bør i fremtiden også gjelde flere typer straffbare handlinger enn i dag. Konfliktrådene bør bli direkte tilknyttet de enkelte politidistrikt i stedet for å være knyttet til kommunene som i dag. Jeg vil ansvarliggjøre politiet som konfliktløser. Ikke slik å forstå at politiet nødvendigvis skal megle sakene selv, men slik at ordningen administreres av politiet. På denne måten kan de enkle sakene megles av politipersoner "på stedet" og de mer kompliserte overlates til en ansatt konfliktrådsleder i politiet, som spiller på frivillige meglere rundt om i politidistriktet. Jeg tror mye av forklaringen på at ordningen enda 
ikke har funnet sin sentrale plass rundt i landet, nettopp henger sammen med at politiet ser ordningen med kommunale ledere som "fjern" og lite integrert $\mathrm{i}$ deres daglige virke. En ny organisering vil gjøre oss til mer "nærpoliti".

Et annet individuelt forebyggende tiltak er bekymringssamtalen. Denne er et strukturert verktøy for samtaler med unge og foresatte om risikoadferd i forhold til kriminalitet. Opplegget er utarbeidet av Manglerud politistasjon i Oslo politidistrikt. Målgruppen for bekymringssamtalen er førstegangslovbrytere og unge som er i risikosonen for å begå lovbrudd. Samtalene brukes både for å kartlegge den unges situasjon, gi veiledning i forhold til skole, arbeid og fritid, og for å planlegge innsats for å sikre en positiv fremtidig utfordring. For å skape det nødvendige nettverk, er det forutsatt at andre etater som barnevern, skole og andre involveres i et tett samarbeid. I år 2000-2001 planlegger Justisdepartementet å iverksette evaluering, materiellutvikling og produksjon av materiell om bekymringssamtalen for oppfølgning av unge i risikosonen og førstegangskriminelle i alle politidistrikt. Slik blir vi mer "nærpoliti".

Et siste individuelt forebyggende tiltak jeg vil nevne er forsøket med ungdomskontrakter slik de har det i Danmark. Ungdomskontrakten er en avtale mellom en ung lovbryter med samtykke av foresatt på den ene siden og politi og kommunale myndigheter på den annen side. I kontrakten forplikter den unge seg til å gjennomføre spesifiserte aktiviteter mot at rettsmyndighetene avstår fra ytterligere rettsforfølgelse. Kontrakten skal inneholde tiltak som bidrar til å endre adferd og gi støtte til å komme inn i et positivt livsløp. Både den unge og familien skal delta i gjennomføringen av kontrakten. Ordningen med ungdomskontrakter vil bli utprøvd i et begrenset omfang i noen kommuner i Norge. Slik blir vi mer "nærpoliti".

\section{Hvordan ser det ut $\mathrm{i}$ vårt politidistrikt}

Vi har ikke lenger noen særskilt forebyggende tjeneste i vårt politidistrikt. Dette arbeidet er inkorporert $\mathrm{i}$ all daglig aktivitet. Vi har etablert forebyggende virksomhet innenfor det vi kaller "røde", "gule" og "grønne" områder. Politidistriktet er inndelt $\mathrm{i}$ aktuelle områder alt etter graden av sårbarhet for kriminalitet. Den enkelte driftsenhet (politistasjon og lensmannskontor) innretter sin forebyggende innsats planmessig innenfor de aktuelle områder.

Med mange små driftsenheter har vi sett betydningen av at de arbeider tett sammen i samarbeidsregioner. I disse regionene er driftsenhetene sammen om arbeidstidsordninger/tjenestelister. De har en del av sitt budsjett $i$ en felles "pott" til dekning av variable utgifter som overtid m.m. i regionen. Vi har god erfaring med dette samarbeidet og vi vil arbeide videre med å bryte ned grensene mellom driftsenhetene. Det er etter hvert mange som mener at vi har for mange små driftsenheter med egen administrasjon og ledelse. For mange ressurser benyttes til å administrere oss selv. Ved å slå driftsenheter sammen flytter man ikke politipersonene, men lar færre ta seg av personalarbeid og plan- og budsjettarbeid. Vi ønsker å frigjøre ressurser til aktivt, utadvendt politiarbeid. 
Visjonen om politiet som en kulturinstitusjon

I vårt politidistrikt har vi en visjon om å være en kulturinstitusjon som tar vare på, anvender og formidler grunnleggende verdier av betydning for samfunnet, som solidaritet og hjelpsomhet, rettferdighet og likeverd, grensesetting, fornyelse og gjenreisning. Dette er en visjon for et politi som ønsker å tjene enkeltmennesket og samfunnet. Nærpolitiarbeid har mest med holdninger å gjøre.

Adresse: Bodø Politidistrikt

N - 8002 Bodø 